\title{
Pewarnaan Benang Menggunakan Ekstrak Daun Nila (Indogofera)
}

\author{
Agrippina Wiraningtyas ${ }^{1}$, Ruslan $^{1,}{ }^{*}$, Ahmad Sandi $^{2}$ dan Muh. Nasir ${ }^{3}$ \\ ${ }^{1}$ Program Studi Pendidikan Kimia STKIP Bima \\ ${ }^{2}$ Program Studi Pendidikan Ekonomi STKIP Bima \\ ${ }^{3}$ Program Studi Pendidikan Biologi STKIP Bima \\ *Email: ruslanabinada@gmail.com
}

\begin{abstract}
ABSTRAK
Telah dilakukan kegiatan pewarnaan benang tenun menggunakan zat warna alam dari daun nila (Indigofera). Metode yang digunakan dalam pengambilan ekstrak zat warna dari daun nila digunakan metode fermentasi. Sedangkan pada pewarnaan benang dilakukan melalui beberapa tahapan yaitu mordanting, pewarnaan, fiksasi dan pengeringan benang. Hasil kegiatan pada proses fermentasi diperoleh ekstrak daun nila berwarna biru gelap dan memiliki aroma khas. Pada proses pewarnaan benang diperoleh benang hasil pencelupan dalam ekstrak daun nila memberikan warna abu-abu. Fiksasi dengan dengan tawas dan kapur menghasilkan benang berwarna biru keabuan sedangkan fiksasi dengan tunjung menghasilkan benang berwarna abu kecoklatan.
\end{abstract}

Kata Kunci : pewarnaan benang, zat warna alam, ekstrak daun nila, metode fermentasi

\section{PENDAHULUAN}

Pembuatan kain tenun Bima saat ini menggunakan benang dengan pewarna sintetis sebagai bahan baku tenun. Untuk menjaga keaslian dan warisan budaya kain tenun Bima perlu dilakukan usaha pelestarian budaya kain tenun Bima dimana proses pewarnaan pembuatan kain tenun Bima menggunakan zat warna alam berbahan baku lokal. Pewarnaan benang dengan pewarna alami banyak memberikan manfaat bagi keberlangsungan alam dan generasi mendatang. Sejalan dengan konsep pembangunan berkelanjutan dan pemanfaatan produk ramah lingkungan, pemanfaatan sumber-sumber pewarna alami yang dulu sempat ditinggalkan kembali dilakukan. Bahkan di beberapa negara maju seperti Jerman dan Belanda telah merealisasikan pelarangan penggunaan zat pewarna sintetik sejak tahun 1996. Oleh karena itu, saat ini sudah bermunculan produk-produk tekstil yang menggunakan bahan pewarna alami seperti kain tenun. Penggunaan pewarna alam pada benang merupakan salah satu tahapan pada pembuatan kain tenun tradisonal Bima secara turun temurun. Pewarna alam memiliki banyak kelebihan diantaranya warna yang dihasilkan lebih natural, sejuk, unik dan indah sesuai karakteristik warna alam, limbah yang dihasilkan lebih ramah lingkungan (biodegradable), ketersediaan bahan baku melimpah (renewable). Kain tenun yang menggunakan bahan pewarna alami akan tebukti memiliki nilai artistik dan sisi eksotiknya tersendiri sehingga berpotensi sebagai komoditas ekspor serta harga yang tinggi. Oleh karena itu perlu dilakukan penggunaan zat warna alam pada pewarnaan benang dalam proses pembuatan kain tenun Bima untuk menghasilkan produk berkualitas tinggi sehingga menjadi produk komoditas unggulan asli Indonesia.

Bahan baku benang yang digunakan dalam pembuatan kain tenun Bima berupa benang sudah diwarnai menggunakan pewarna sintetik. Pewarna sintetik memiliki warna yang lebih beragam, tidak mudah luntur, mudah diproduksi, proses pewarnaan kain lebih mudah dan biayanya murah. Namun, pewarna sintetik bersifat karsinogenik dan berbahaya bagi lingkungan sehingga mengurangi nilai artistik dan sisi eksotiknya. Pewarna sintetik 
mengandung senyawa yang tidak mudah terdegradasi oleh lingkungan. Limbah yang dihasilkan dari proses produksi industri tekstil juga mengandung logam berat seperti kromium ( $\mathrm{Cr}$ ), timah (Sn), tembaga (Cu) dan seng ( $\mathrm{Zn}$ ) [8]. Oleh karena itu, pada kegiatan ini dilakukan pewarnaan benang menggunakan zat warna alam. Material benang pada umumnya sulit berikatan dengan zat warna. Oleh karena itu, sebelum dilakukan pewarnaan pada benang dilakukan proses mordanting untuk menghilangkan pengotor yang menempel pada benang. Untuk memperoleh zat warna yang mempunyai ketahanan luntur baik maka perlu dilakukan proses fiksasi zat warna. Fiksasi dapat berfungsi memperkuat warna dan merubah zat warna alam sesuai dengan jenis logam yang mengikatnya serta mengunci zat warna yang telah masuk kedalam serat. Bahan yang biasa digunakan untuk fiksasi adalah tawas $\left[\mathrm{K}_{2} \mathrm{SO}_{4} \cdot \mathrm{Al}_{2}\left(\mathrm{SO}_{4}\right)_{3} \cdot 24 \mathrm{H}_{2} \mathrm{O}\right]$, kapur $\left(\mathrm{CaCO}_{3}\right)$ dan tunjung $\left(\mathrm{FeSO}_{4}\right)[13]$.

\section{METODE}

\section{Alat dan Bahan}

Adapun alat dan bahan yang digunakan dalam kegiatan ini adalah sebagai berikut: Alat yang digunakan dalam penelitian ini adalah: ember, pengaduk, penyaring, tempat penjemuran. Bahan yang digunakan dalam kegiatan ini adalah: daun nila (indigofera), benang putih, air, tawas, tunjung dan kapur.

\section{Proses Fermentasi}

Daun nila kering direndam dalam air selama kurang lebih 2-3 hari kemudian disaring. Filtrat yang diperoleh ditambahi kapur tohor dan diaduk selama 1 jam dan terbentuk endapan. Endapan yang terbentuk digunakan sebagai pewarna alam dalam jangka waktu lama.

\section{Tahap Mordanting}

Sebelum dilakukan proses pewarnaan, benang terlebih dahulu dimordanting menggunakan tawas pada suhu $60{ }^{\circ} \mathrm{C}$ selama 1 jam, selanjutnya dijemur.

\section{Tahap Pewarnaan}

Benang yang sudah dimordanting selanjutnya dicelupkan dalam zat warna selama 24 jam kemudian dijemur selama 30 menit. Selanjutnya benang dicelup kembali selama 30 menit dan dijemur sampai kering.

\section{Tahap Fiksasi}

Benang yang sudah diwarnai selanjutnya difiksasi masing-masing dengan tunjung, tawas dan kapur tohor melalui perendaman selama 5 menit kemudian dijemur selama 30 menit selanjutnya direndam kembali selama 5 menit dan dijemur sampai kering.

\section{Membuat Larutan Fiksasi}

- Larutan fixer tunjung : larutkan 70 gram tunjung dalam tiap liter air yang digunakan. biarkan mengendap dan ambil larutan beningnya.

- Larutan fixer tawas : larutkan 70 gram tawas dalam tiap liter air yang digunakan. biarkan mengendap dan ambil larutan beningnya. 
- Larutan fixer kapur tohor : larutkan 70 gram kapur tohor dalam tiap liter air yang digunakan. biarkan mengendap dan ambil larutan beningnya.

\section{HASIL DAN PEMBAHASAN}

\section{Pembuatan Ekstrak Daun Nila}

Pada kegiatan pembuatan zat warna alam dari daun nila dilakukan dengan metode fermentasi. Daun nila kering terlebih dahulu dicuci menggunakan air kemudian dilakukan fermentasi. Proses fermentasi dilakukan dengan merendam daun nila kering dalam air selama beberapa hari sehingga diperoleh ekstrak daun nila yang berwarna biru dan beraroma khas. Warna yang dihasilkan seperti pada gambar 1 berikut.

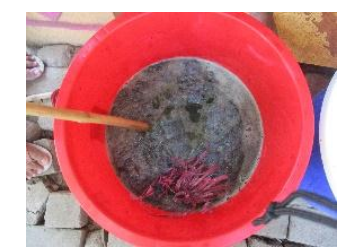

Gambar 1. Ekstrak daun nila

\section{Proses Mordanting Benang}

Benang yang digunakan pada pewarnaan terlebih dahulu di lakukan mordanting untuk menghilangkan kotoran yang menempel pada benang. Benang dimasak dalam larutan tawas selama 30 menit kemudian dijemur selama 1 jam.
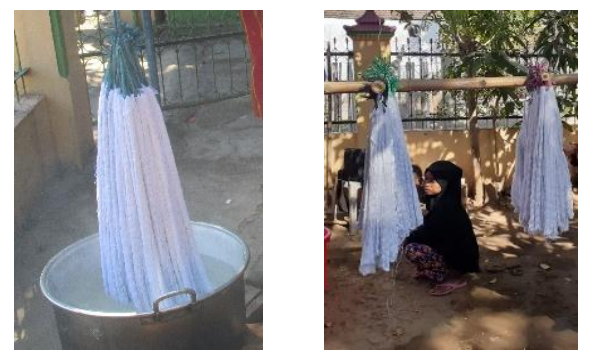

Gambar 2. Proses mordanting

\section{Proses Pewarnaan Benang}

Benang yang sudah dimordanting selanjutnya dicelup ke dalam ekstrak daun nila Proses pewarnaan benang seperti pada gambar 3. Proses pewarnaan dilakukan selama 24 jam selanjutnya ditiriskan untuk mengurangi kadar air. Kemudian dicelupkan lagi selama 30 menit sebanyak 2 kali. Hal ini dilakukan untuk mendapatkan warna yang homogen pada permukaan benang.
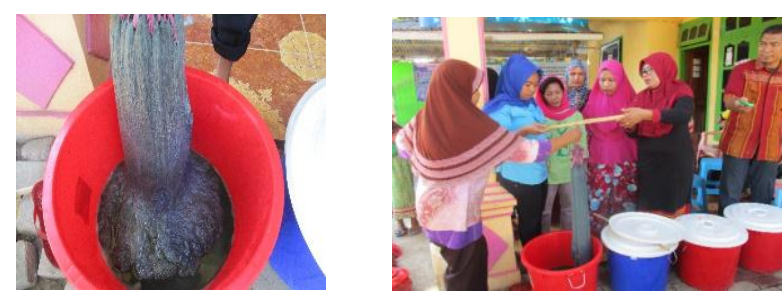

Gambar 3. Pewarnaan Benang 
Warna pada benang akan mudah luntur apabila dicuci dengan air. Maka proses selanjutnya yaitu melakukan pengikatan zat warna pada benang yang disebut dengan proses fiksasi. Bahan yang biasa digunakan pada proses fiksasi adalah tawas, tunjung dan kapur. Dengan proses fiksasi dapat meningkatkan kualitas zat warna pada benang dan warna yang dihasilkan akan bervariasi tergantung pada zat pengikatnya meskipun dari sumber zat warna yang sama.
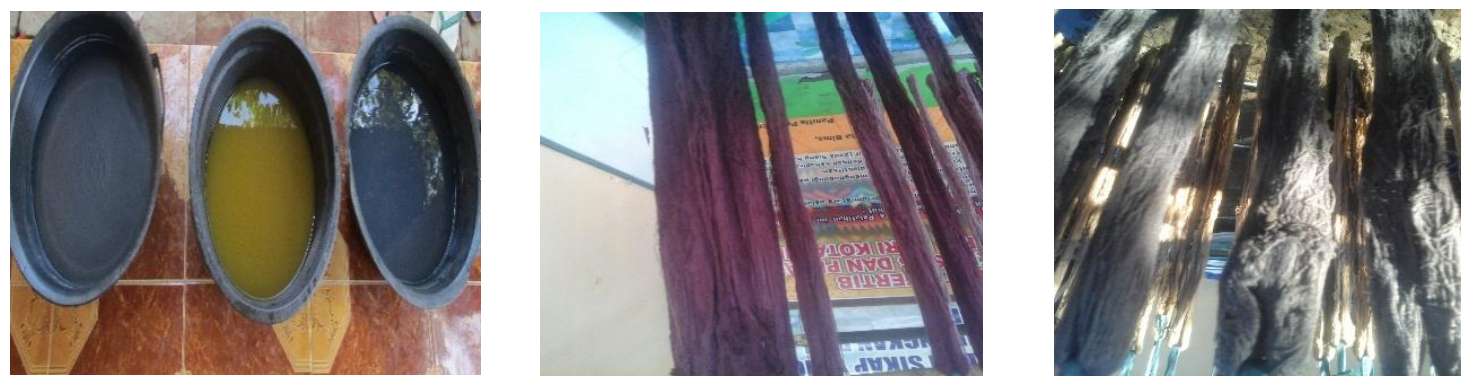

Gambar 4. Proses Fiksasi

Benang yang sudah difiksasi kemudian dijemur sampai kering dan selanjutnya dilakukan pencucian dengan air untuk mendapatkan benang dengan warna yang stabil. Proses penjemuran benang seperti ditunjukkan pada gambar 5 .

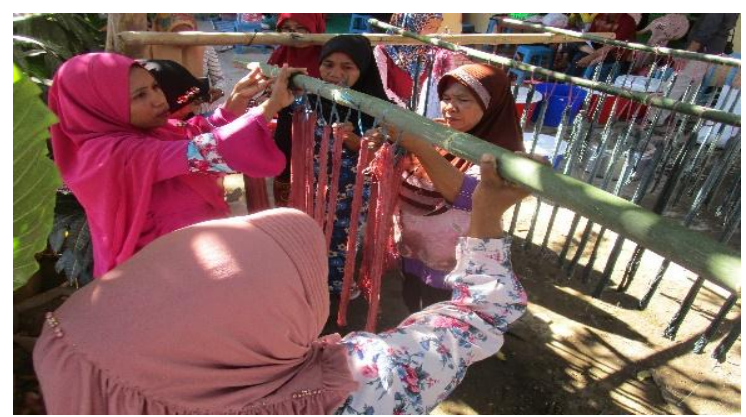

Gambar 5. Proses penjemuran benang

Hasil akhir pada kegiatan pewarnaan benang diperoleh produk benang dengan warna bervariasi seperti ditunjukkan pada katalog benang berikut.

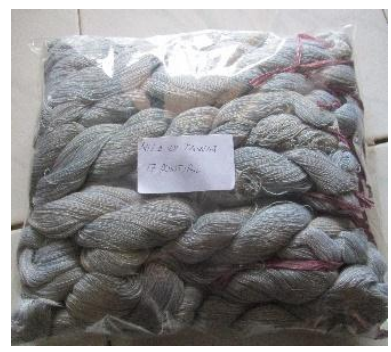

a

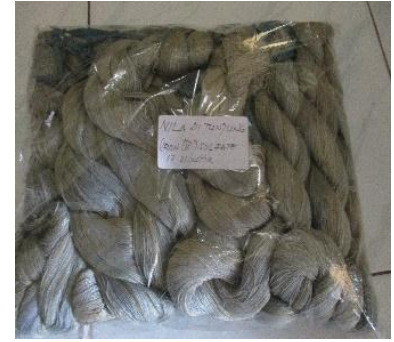

b

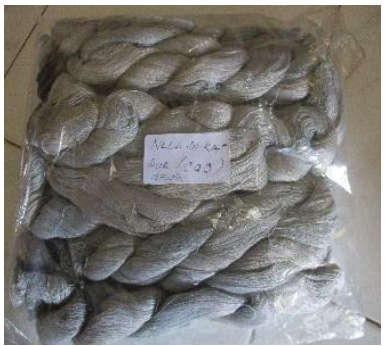

C

Gambar 6. Benang hasil pewarnaan dari ekstrak kulit kayu mahoni pada fiksasi a) tawas; b) tunjung dan c) kapur 
Berdasarkan hasil tersebut, produk benang yang dicelupkan pada zat warna dari daun nila (indigofera) menghasilkan warna abu-abu. Setelah dilakukan fiksasi dan pencucian diperoleh mengalami perubahan warna yaitu menjadi biru keabuan pada fiksasi tawas, abu kecoklatan pada fiksasi tunjung dan menjadi biru pada fiksasi kapur.

\section{KESIMPULAN}

Berdasarkan pembahasan diatas dapat disimpulkan bahwa ekstrak daun nila (Indigofera) dapat digunakan dalam pewarnaan benang. Ekstrak yang dihasilkan berwarna biru. Setelah dilakukan pewaraan dan fiksasi, produk benang yang dihasilkan memiliki warna biru keabuan, dan abu kecoklatan.

\section{UCAPAN TERIMAKASIH}

Penulis mengucapkan terimakasih kepada Direktorat Riset dan Pengabdian kepada Masyarakat Direktorat Jenderal Penguatan Riset dan Pengembangan Kementerian Riset, Teknologi dan Pendidikan Tinggi Republik Indonesia yang telah mendanai Pengabdian pada Masyarakat ini melalui skim PPPUD tahun 2019.

\section{DAFTAR PUSTAKA}

Hartanto, N.S., Watanabe, S., 2003, Teknologi Tekstil, Jakarta, Pradnya Paramita.

Inayat, A., Khan, S.R., Waheed, A., Deeba, F. 2010. Application of Ecofriendly Natural Dyes on Leather using differen Mordants. Proc. Pakistan Acad. Sci. 47 (3); 131-135.

Indrianingsih, A.W., Darsih, C., Maryana, R. 2013. Pewarna Alam dari Ekstrak Tanaman dan Aplikasinya di Usaha Kecil Menengah Tekstil Indonesia. Prosiding Seminar Nasional Kimia dan Pendidikan Kimia V. PKIM FKIP UNS. 682-691.

Lusiana, M., Livia, M., Maria, P., Fransisca, L. 2005. Elevation of The Clastogenicity and Anticlastogenicity of The Carotenoid Bixin in Human Lymphocyte Cultures. Mutation Research. 585; 114.

Mubin, I. 2016. Makna Simbol atau Motif kain Tenun Khas Masyarakat Daerah Bima di Kelurahan Raba Dompu Kota Bima Provinsi Nusa Tenggara Barat. Historis. 1 1, 21-24.

Paryanto, Kridyantoro, R., Prabowo, Y.S. 2015. Pembuatan Zat Warna Alami berbentuk Bubuk dari Biji Kesumba. EKUILIBRIUM. 14 1, 13-16.

Pujilestari, T., 2014, Pengaruh Ekstraksi Zat Warna Alam dan Fiksasi Terhadap Ketahanan Luntur Warna pada Kain Batik Katun, Dinamika Kerajinan dan Batik, 31 1, 7-9.

Utami, P. 2017. Tenun Jadi Produk Unggulan Kota Bima. PLUT Kota Bima.

Wahid, H. 2006. Tenunan dan Wanita Bima. Dinas Pemberdayaan Masyarakat dan Perempuan. Kota Bima. 22.

Wijaya, S.I. Ardana, I.G.N.S. Mursal. 2012. Kerajinan Tenun Songket Bima di Lingkungan Nggaro Kumbe Kelurahan Rabadompu Timur Kecamatan Raba Kota Bima Provinsi NTB. Jurusan Pendidikan Seni Rupa. Universitas Pendidikan Ganesha. Singaraja.

Wiraningtyas, A. 2019. Ekstraksi Zat Warna Dari Rumput Laut Sargassum Sp. Jurnal Redoks: Jurnal Pendidikan Kimia Dan IImu Kimia, 2 1, 1-10. 